\title{
COMPARATIVE AND LEGAL STUDY ON CRIMINAL PROTECTION IN THE BANKING ACTIVITY SPHERE ${ }^{1}$
}

\author{
Klochko A. M., Volchenko N. V.
}

\section{INTRODUCTION}

The current Association Agreement between Ukraine and the European Union (replaced the Partnership and Cooperation Agreement between the European Communities and Ukraine) provided a real transition from partnership and cooperation to present economic integration and political association. The entry into force of this Agreement implies the need for adaptation measures in all spheres of Ukrainian legislation. The banking sector is no an exception. The integration of the banking sector of Ukraine into the European one implies the implementation of specific measures in such areas as ensuring stability, increasing competitiveness (especially in the sphere of banking services), preventing and reducing risky situations, structural reorganization and so on. Any changes can cause uncertainty and instability, which encourages the emergence of dangerous situations ${ }^{2}$.

The evolution of society implies the development of all vital and socially important spheres of its functioning, both existing social relations and the gradual formation of new ones, in particular those that have arisen due to the influence of various external factors. Public relations, which have emerged and are dynamically developing in the sphere of banking activity of Ukraine, due to their comprehensive connection with many other spheres of society's life, require a high level of protection in order to ensure their effective functioning. The existence of effective securing norms in the system of national criminal law can increase the security's level of these types of relationships and the entire banking system. Crimes in the field of banking create a threat to the safety functioning of the economy, which can result in a threat to the national security of any country in the world. Criminal elements, having close interregional and international ties, are increasingly focusing their efforts on establishing control over the most profitable areas of economic relations ${ }^{3}$.

\footnotetext{
1 An article is prepared in the frames of the project for the young scientists of Ukraine of 2017 (project ID 96737) "Improvement of the legislation of Ukraine as to the provision of the protection of the banking in the conditions of European integration: economic and legal aspect"

2 Волченко Н.В., Клєцова Н.В. Правові засади банківської безпеки в контексті європейської інтеграції України. Юридичний науковий електронний журнал. 2017. № 6. С. 127-130. URL: http://www.lsej.org.ua/6_2017/36.pdf (дата звернення: 11.01.2020).

3 Клочко А.М. Досвід зарубіжних країн у сфері боротьби зі злочинністю. Європейські перспективи. 2012. № 3, ч. 2. С. 132-135.
} 
Criminal prohibitions are aimed at preventing crimes under the threat of penalties imposed by law. The absence of legal prohibitions at the legislative level deprives public relations of protection. This can be a significant problem in the context of dynamic development, in particular in areas related to the turnover of significant financial resources, which primarily belong to the banking sector.

Consequently, the focus of Ukraine's foreign policy on European and Euro-Atlantic integration, the need to streamline national legislation in accordance with world standards, the democratization of social and political relations at the domestic and international levels determines the timeliness of comparative studies in various fields of law ${ }^{4}$. We can also say that the Criminal Code is outdated. It separated the old norms of the Soviet era from the new - the times of independent Ukraine. Working groups on criminal law's codification, formulating the objectives of the new criminal law, emphasized the usage of world experience, the most appropriate legal decisions made by the laws and practices of other countries ${ }^{56}$. In our opinion, it is undoubtedly necessary to take into account current trends in the development of criminal protection in the banking activity sphere in foreign countries, especially EU's countries. They are real providers of modern practice in achieving banking security. To confirm this fact we turn to the statement from the work of O.N. Grebenyuk. According to him, it is necessary to take into account the current trends in the development of the financial environment: the threats are constantly changing, expanding, transforming and fundamentally new; new risks emerge and their cumulative effects occur, customer expectations increase in the face of scarce resources, new technologies and analytical tools emerge. First of all, it is necessary to put into bank's practice European traditions and a culture of work with risks. It involves the usage of analytical talents of certain specialists and technical capabilities of modern technologies ${ }^{7}$.

\footnotetext{
4 Каменський Д.В. Кримінальна відповідальність за податкові злочини за федеральним законодавством США : автореф. дис. на здобуття наук. ступеня канд. юрид. наук : спец. 12.00.08 «Кримінальне право та кримінологія; кримінально-виконавче право». Київ, 2010. 20 с.

5 Волженкин Б.В. Экономические преступления. Санкт-Петербург: Юридический центр Пресс, 1999. 312 с.

6 Панов В.П. Международное уголовное право : учебное пособие. Москва, 1997. 241 с.

7 Гребенюк О.Н. Фінансова безпека банків: система розпізнання загроз та усунення ризиків. Вісник Харківського національного університету імені В.Н. Каразіна. Серія «Економічна». 2016. Вип. 91. С. 62.
} 


\section{Adaptation of Ukrainian legislation on banking activities in the framework of Eurointegration}

We consider the European experience to be a priority for the domestic criminal legislation's formation regarding the elimination of gaps in the banking sector's security. This is first and foremost related to the approval of the Concept of the National Program on Ukrainian Legislation Adaptation to the Legislation of the European Union (Law of Ukraine on November 21, 2002) $)^{8}$. In 2004, the Law of Ukraine "On the National Program of Ukrainian Legislation Adaptation to the Legislation of the European Union" was adopted. The provisions of the Law stipulate that the purpose of Ukrainian legislation adaptation to EU's legislation is to achieve compliance of the Ukrainian legal system with the acquis communautaire, taking into account the criteria put forward by the EU to the states that intend to join it. Adaptation of the Ukrainian legislation to the EU's legislation is a priority of Ukraine's integration the EU. Eurointegration is a priority of Ukrainian foreign policy9.

Visa Liberalization Action Plan approved on November 22, 2010 is essential for Ukraine's further European integration ${ }^{10}$. According to this Action Plan Ukraine envisages a series of legislative acts of four blocks, namely: document security, including biometrics (block 1); illegal immigration, in particular readmission (block 2); public order and security (block 3); external relations and fundamental rights (block 4).

In the context of criminal protection of banking, we are interested in the third block. Block 3 of the Visa Liberalization Action Plan provides for the phased approval and implementation of:

- a comprehensive strategy on the fight against organized crime accompanied with the Action Plan;

- Law of Ukraine "On Combating Trafficking of Human Beings";

- legislation to prevent and combat corruption;

8 Про Концепцію Загальнодержавної програми адаптації законодавства України до законодавства Європейського Союзу : Закон України від 21 листопада 2002 р. 228-IV. Відомості Верховної Ради України. 2003. № 3. Ст. 12.

9 Про Загальнодержавну програму адаптації законодавства України до законодавства Європейського Союзу : Закон України. Відомості Верховної Ради України (ВВР). 2004. № 29. Ст. 367. URL: https://zakon.rada.gov.ua/laws/show/1629-15 (Last accessed: 14.02.2020).

10 Безвізовий діалог між Україною та ЄС. План дій з лібералізації візового режиму. Схвалено на саміті Україна - Свропейський Союз 22 листопада 2010 р., м. Брюссель, Королівство Бельгія. URL: http://zakon2.rada.gov.ua/laws/show/984_001/paran2\#n2 (Last accessed: 14.02.2020). 
- a national strategy to combat money laundering and terrorism financing, including the adoption of a law on the prevention of terrorism financing;

- the new National Strategic Program on the Fight Against Drugs and the relevant Action Plan, in particular the ratification of the Memorandum of Understanding with the European Monitoring Centre for Drugs and Drug Addiction;

- the relevant United Nations' and Council of Europe's Conventions in the above fields, as well as the fight against terrorism;

- judicial cooperation in criminal matters (adoption of the legislative framework on mutual legal assistance, ratification of the Second Protocol to the European Convention on Mutual Legal Assistance; conclusion of an agreement with the EU, implementation of international conventions on judicial cooperation in criminal law's matters);

- law enforcement cooperation;

- data protection (ratification of relevant international conventions, such as the Council of Europe Convention on the Protection of Individuals with regard to Automatic Processing of Personal Data and its Additional Protocol 2001, implementation of the Law on Personal Data Protection, etc. $)^{11}$.

The tasks identified in the provisions of Block 3 of the Visa Liberalization Action Plan cover a wide range of cooperation between Ukraine and the EU, including the improvement of legislation on banking security, anti-money laundering and other types of abuse. Thus, the adaptation and harmonization of national legislation to the European is a priority component of the process of Ukraine's future integration into the EU.

However, despite repeated intentions at the highest level to intensify European integration, in practice there are little-understood chaotic processes of the so-called "optimization" of institutions responsibility for European integration course's implementation, in particular in the area of legislative approximation ${ }^{12}$.

\footnotetext{
11 Матвійчук В.К., Гіда О.С., Прилуцький Р.Б. та ін. Протидія злочинності та адаптація кримінального законодавства і права України до законодавства і права Європейського Союзу : монографія. / за заг. ред. д-ра юрид. наук, проф. В.К. Матвійчука. Київ : ВНЗ «Національна академія управління», 2014. 552 с.

12 Трюхан В. Інституційне забезпечення адаптації законодавства України до надбання спільноти в рамках виконання майбутньої Угоди про асоціацію Україна - ЄС. Вісник Національної академії державного управління. 2011. № 4. C. 232. URL: http://visnyk.academy.gov.ua/ wp-content/uploads/2013/11/2011-4-31.pdf (Last accessed: 20.01.2020).
} 
The fight against crime and corruption is recognized as a priority of the EU-Ukraine Association Agreement. This determines the particular importance of specific measures at the current stage of the process. Part 1 and Part 2 of Art. 22 of the Agreement on "Combating Crime and Corruption" establishes that the parties cooperate in the fight against criminal and illegal organized or other activities, as well as for the purpose of preventing them.

The generalization is presented in Fig. 1 (see p. 704). All aspects and measures that need to be implemented in the adaptation process must be implemented in a clearly defined manner. It is not only scientifically grounded, but also tested but also proved in the process of implementation by other countries seeking European integration. Adaptation of the legislation to the requirements of the EU Directives should be made within the framework of amendments to certain legislative acts of Ukraine.

Among those of interest according to the research topic can be defined legislative acts: on liberalization of foreign exchange transactions to facilitate investments and exports, improve the system of guaranteeing deposits of individuals and procedures for removing banks from the market, ensuring transparency of National Bank of Ukraine activities and increasing banks' accountability, as well as improving the provisions of criminal law to protect the rights of banking services' consumers, creditors, responsibility of bank employees, the criminalization of activities in banking, containing elements of social danger. 


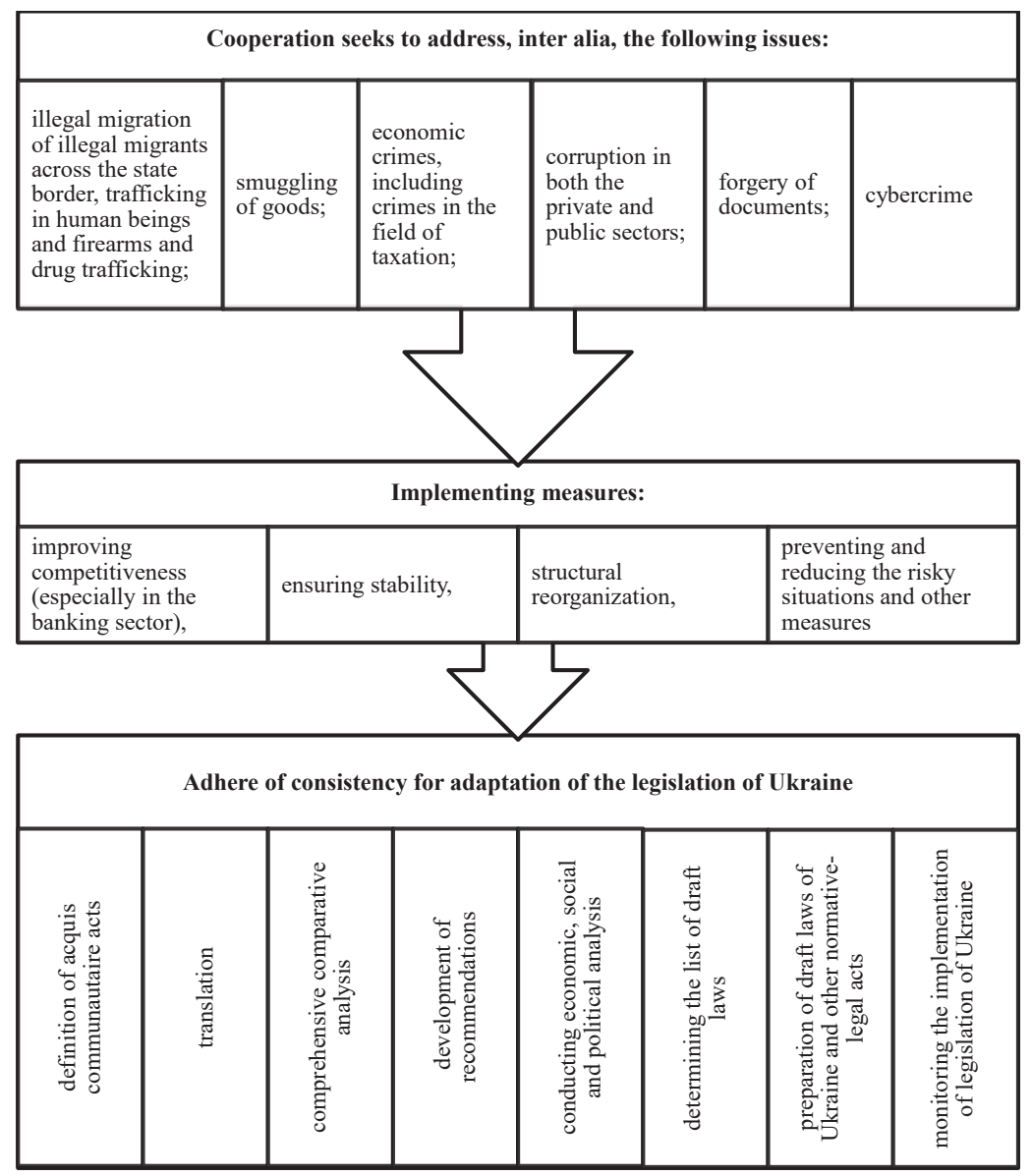

Fig. 1. Generalization of adaptation measures in all spheres of Ukrainian legislation

Source: compiled by authors on the basis of ${ }^{13}$

13 Безвізовий діалог між Україною та ЄС. План дій з лібералізації візового режиму. Схвалено на саміті Україна - Свропейський Союз 22 листопада 2010 р., м. Брюссель, Королівство Бельгія. URL: http://zakon2.rada.gov.ua/laws/show/984 001/paran2\#n2 (Last accessed: 14.02.2020).

Про Загальнодержавну програму адаптації законодавства України до законодавства Європейського Союзу : Закон України. Відомості Верховної Ради Украӥни (ВВР). 2004. № 29. Cт. 367. URL: https://zakon.rada.gov.ua/laws/show/1629-15 (Last accessed: 14.02.2020).

Угода про асоціацію між Україною, з однієї сторони, та Європейським Союзом, Європейським співтовариством з атомної енергії і їхніми державами-членами, з іншої сторони. Редакція від 30.11.2015, підстава - v2980321-15. URL: https://zakon.rada.gov.ua/laws/show/984_011 (Last accessed: 10.09.2019). 
In considering the criminal law experience of Ukraine and the countries of Europe, the following facts should be emphasized. The criminal law experience of European countries differs in duration compared to domestic. In particular, the German Criminal Code has existed for over 100 years, Italy -80 years, Switzerland - 70 years, etc. The Criminal Code of France in 1992 replaced the previous version, which had been in force since 1810 . A.S. Nersesian emphasized that at the present stage of society development, globalization of the world economy, integration of production capacities of different states, there is a process of legal systems integration also ${ }^{14}$.

The problem of crimes in the field of banking is deeply researched by leading world companies and rating agencies. In particular, the US International Business Machines Corporation (IBM) provides the following statistics in its reports: the total cost of projects subject to fraud is $\$ 4.7$ trillion per year; $71 \%$ of bank clients seek to change the servicing banking institution precisely because of the low level of security; $65 \%$ of clients will never cooperate with non-confidential banks again; $85 \%$ of respondents say they will share their experience with other bank customers about the improper level of security ${ }^{15}$.

It is important to note that bank secrecy, confidentiality of information and deposit guarantee affect the positive image of the bank's corporate image. Deposits of individuals are guaranteed in the manner stipulated by the legislation of Ukraine. Improper banking secrecy adversely affects consumer cooperation with banks and causes them to refuse banking services. The regulation of relations between bank and client by means of the national legislation (normative legal acts of the NBU and agreements between the client and the bank) are a guarantee of keeping bank secrecy.

\section{The criminal law in banking activity: experience of European countries}

Surveys of Deloitte International Company show that $93 \%$ of respondents say that the level of fraud in the banking sector has increased significantly over the last two years. Given the significant losses, banking institutions should develop appropriate measures to enhance the reputation of banks ${ }^{16}$. EU criminal law contains rules aimed at protecting the rights of creditors.

\footnotetext{
14 Нерсесян А.С. Кримінально-правова охорона прав інтелектуальної власності. Хмельницький : Видавництво Хмельницького університету управління та права, 2010. 192 с.

15 Fighting fraud in banking with big data and analytics. White paper. IBM Corporation Software Group. URL: http://www-07.ibm.com/au/pdf/Fighting_Fraud_in_Banking_with_Analytics.pdf.

16 Jayaprakash Nair. Analytics Applied - Fraud prevention and detection in the Banking sector. URL: http://blog.aspiresys.com/digital/big-data-analytics/analytics-applied-fraud-prevention-anddetection-in-the-banking-sector/ (Last accessed: 15.12.2019).
} 
Even without being a member of the European Union, Switzerland is an interesting experience for us in the research area. For example, the Criminal Code of Switzerland ${ }^{17}$ contains articles $163-170$ that protect the interests of creditors: false bankruptcy and fraud on foreclosed property (Art. 163); reduction of assets to the detriment of creditors (Article 164); mismanagement (Article 165); inability to keep accounts in the manner prescribed by law (Article 166); favoring the creditor and accepting the debt by the creditor to the detriment of the interests of other creditors (Art. 167); subordination in enforcement proceedings (Article 168); disposal of seized assets (Art 169); agreement on the composition of the court in a fraudulent way (Article 170).

Art. 162 of the Swiss Criminal Code contains a rule on the disclosure of commercial secrecy. Notable that unlike Art. 232 of the Ukrainian Criminal Code "Disclosure of Commercial or Banking Secrecy", Art 162 of the Criminal Code of Switzerland "Breach of manufacturing or trade secrecy" is formulated in such a way that it does not combine the disclosure of commercial and banking secrecy in the same criminal norm. Obviously, this is due to the fact that the Swiss legislature distinguishes banking and trade secrecy as separate objects of criminal protection. In particular, according to Art. 162 of the Criminal Code of Switzerland: "Any person who discloses industrial or commercial secrecy, of which it is aware in accordance with its legal or contractual obligations, any person who uses such information for personal purposes of third parties is subject to imprisonment for a term not exceeding three years, or a fine".

Another feature of Swiss criminal law is the subjective elements of banking crimes. In particular, in the Art. 163-170 of the Criminal Code, it is meaningfully defined - it is a debtor, and in qualifying crime (in particular, part 2 of Art. 163, part 2 of Art. 164 and in Art. 170 of the Criminal Code) it is also a third party acting in the interests of the debtor.

For example, in Part 2 of Art. 164 of the Criminal Code of Switzerland "Reduction of assets to the detriment of creditors" states: "Subject to the same requirements, any third party who commits any of the foregoing actions to the detriment of creditors shall be punished by imprisonment not exceeding three years, or a fine" $" 18$.

17 Кримінальний кодекс Швейцарії від 21.12.1937 р. (станом на 12.07.2012р.). URL: http://law.edu.ru/norm/norm.asp?normID=1241950\&subID=100098712,100098714, 100098872,100099142,100099154 \#text (Last accessed: 22.10.2019 p.)

18 Кримінальний кодекс Швейцарії від 21.12.1937 р. (станом на 12.07.2012 p.). URL: http:// law.edu.ru/norm/norm. asp?norm ID=1241950\&subID=100098712,100098714,100098872,10009 9142, 100099154 \#text (Last accessed: 22.10.2019). 
Also, the analysis of the above-mentioned criminal codes reveals that the creditor is the victim of these crimes. In our opinion, a positive feature of Switzerland's criminal law is the specified subjective nature of the crimes in the banking sector, in particular: the debtor or a third party acting in favor of the debtor. The victim of a crime under the law of this state is a creditor (natural or legal person) whose interests have been caused harm.

In our opinion, particular attention should be paid to the experience of countries that have been in the last wave of EU enlargement and have certain common historical features Ukraine.

Criminal liability for crimes in the field of banking is also provided for in Polish law. Yes, in Art. 297 of the Criminal Code of the Republic of Poland states ${ }^{19}$ : "Who, in order to obtain for himself or for another person a loan, bank loan, loan guarantee, subsidy, subvention or public order, provides false or forged documents or false written evidence relating to circumstances that are material to obtaining such a loan, a bank loan, a credit guarantee, a grant, a subsidy or a public order shall be punishable by imprisonment for a term between 3 months and 5 years".

In this context, in Part 3 of Art. 297 of the Criminal Code of the Republic of Poland, the legislator also provided an encouraging provision, according to which the persons who had prevented the illegal use of the loan prior to the criminal prosecution were exempted from punishment. Art. 299-302 of the Criminal Code of Poland establish responsibility for other abuses in the field of banking.

The Criminal Code of Ukraine has made some progress towards protection the rights of creditors, but the dispositions of these norms are formed in such a way that they do not establish direct responsibility for relatively common actions related to attempts to illegally obtain credit. The effect of these norms, in particular Art. 190 of the Criminal Code of Ukraine "Fraud" and Art. 222 of the Criminal Code of Ukraine "Fraud with financial resources", applies, first of all, to other public relations, and on the basis that they are placed in the section "Crimes against property" and Section VII "Crimes in the field of economic activity", public relations, related to securing property rights and those emerging in the field of economic activity. In most banking institutions, there is a stand or monitor that provides information about the search for fraudulent borrowers who have committed fraudulent actions with the bank's credit resources. Again we emphasize that in Ukraine non-compliance with the terms of the bank

19 Кримінальний кодекс Республіки Польща від 01.01.1997 p. URL: http://aw.edu.ru/norm/ norm.asp?normID=1246817\&subID=100110056,100110058\#text (Last accessed: 20.10.2019). 
deposit agreement qualifies specialists as fraud. German criminal law contains rule 265b "Obtaining credit fraudulently", which is contained in section 22 of the Criminal Code of Germany. Such an act is subject to imprisonment for no more than three years or a fine ${ }^{20}$.

The Criminal Code of Bulgaria contains in Part 6 Section I a "Crimes against creditors" 21 , which provides 5 criminal norms aimed at securing the interests of creditors. In particular, these provisions are set out in Art. 227b - 227e. For example, Art. 227 b of the Criminal Code of Bulgaria provides: "A person who becomes insolvent and fails to notify the court within thirty days of payments' suspension shall be punished by imprisonment for a term up to three years or a fine of up to BGN 5.000. The penalty under paragraph 1 is imposed on persons who are obliged to notify the Bulgarian National Bank about a bank which has become insolvent under the Law on Credit Institutions, as well as persons who have been obliged to notify the Financial Supervision Commission on insolvency of the insurer or reinsurer in accordance with the Insurance Code if they have not done so.

According to Art. $227 \mathrm{c}$ : "A person (trader) who, on initiation of bankruptcy proceedings: 1) conceals, destroys, damages or disposes of free amounts of money, securities or other valuables that may satisfy the interests of his creditors; 2) alienates amounts of money, securities or other valuables that may satisfy his creditors if what has been transferred exceeds significantly what has been received and has been performed contrary to generally accepted norms of law; 3) conceals any of its receivables; 4) acknowledges, accepts or fulfills a non-existent obligation; 5) receives a loan, aware of his inability to repay it; 6) delivers credit goods, money, securities or other valuables in his possession in a manner contrary to the ordinary course of business; 7) satisfies only one or more creditors in violation of the law or secures their interests contrary to the interests of all other creditors.

The aforementioned acts, if they caused large damages, shall be punished by imprisonment for a term of three years. Particularly qualified elements of these acts are punished by imprisonment for a term of three to fifteen years ${ }^{22}$.

\footnotetext{
20 German Criminal Code (as amended up to Act of October 30, 2017). URL: https://ec.europa.eu/anti-trafficking/sites/antitrafficking/files/criminal_code_germa-ny_en _1.pdf (Last accessed: 23.11.2019).

21 Criminal Code of the Republic of Bulgaria (1968, amended 2017) (English version). URL: file:/// C:/Users/Пользователь/Downloads/Bulgaria_Criminal_Code_1968_am2017_ENG.pdf (Last accessed: 23.11.2019).

22 Criminal Code of the Republic of Bulgaria (1968, amended 2017) (English version). URL: file:/// C:/Users/Пользователь/Downloads/Bulgaria_Criminal_Code_1968_am2017_ENG.pdf (Last accessed: 23.11.2019).
} 
There is also EU experience on collective liability for crimes. Article 3 of the Law of the Republic of Poland "On the Liability of Collective Entities for Actions Prohibited under the Threat of Punishment" of October, 282002 defines the criminal liability of a legal person as the misconduct of an individual who: 1) act on behalf or for the benefit of a collective entity within the authority or obligations of its representation, make decisions on its behalf, or exercise internal control, or in the event of exceeding the delegated authority or improper performance of the individual's assigned responsibilities; 2) acts in excess of authority or improperly performs his/ her duties; 3 ) act in the interest of or on behalf of the collective entity with the consent or knowledge of the person referred to in paragraph 1 of this Article; 4) is an entrepreneur ${ }^{23}$.

Another common feature of EU law is the indication that a criminal act must be committed in the interests and for the benefit of the legal person. Article 5 of the Criminal Code of Belgium (as amended by the Law of May, 4 1999) states that legal persons are criminally responsible for crimes committed for the purpose of profit ${ }^{24}$.

\section{Analysis of the provisions of us criminal law on banking protection}

Research on the protection of the banking sector at the criminal level should not be confined solely to the experience of European law. In the United States were developed measures aimed at securing the interests of banking customers and creditors. This was due to the active development of trading activities and the commercial component of operation.

The analysis of the provisions of the US criminal law on the protection of banking security is due to the fact that for many years this country has a leading position in the world economy and is the most attractive highly developed country. The economies of individual US' states can be compared with those of independent countries, and all efforts of the state, including the formation of the regulatory framework, are aimed at ensuring the most effective enforcement of laws in all spheres of society.

According to A.P. Buryak, the development of the US banking system, as well as other developed economies, was caused by legislative and institutional changes in the banking activities that were formed in the process of historical development. Such experience can be useful for

23 Грищук В.К., Пасєка О.Ф. Кримінальна відповідальність юридичних осіб: порівняльно-правове дослідження : монографія. Львів : Львівський державний університет внутрішніх справ, 2013. 248 c.

24 Ibid. 
improving the domestic banking system ${ }^{25}$. According to A.V. Savchenko, the comparison of the criminal legislation of Ukraine and the USA is objectively justified, since it gives an opportunity to form a complete and systematic idea of the essence, correlation and other characteristics of the analyzed legislation, its conformity with modern methodological principles, theoretical and applied prerequisites, and use positive foreign experience to improve national criminal justice standards ${ }^{26}$. We have summarized the factors that give rise to our increased interest in analyzing US criminal law on banking business' security, and prove that such actions are appropriate (Fig. 2).

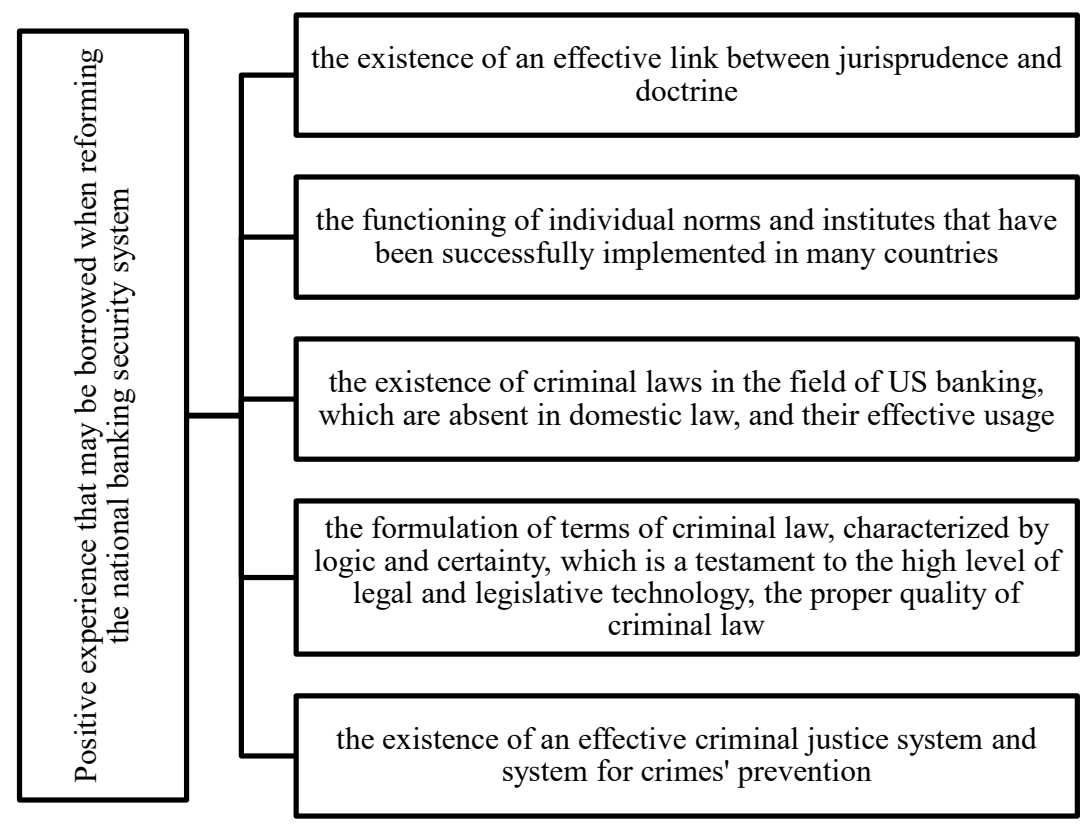

\section{Fig. 2. Factors of increased interest in the research of US experience in criminal protection of banking sector}

Source: compiled by authors

\footnotetext{
25 Буряк О.П. Банківська система США. Сталий розвиток економіки. Міжнародний науково-виробничий журнал. 2015. № 1.

26 Савченко А.В. Порівняльний аналіз кримінального законодавства України та федерального кримінального законодавства Сполучених Штатів Америки : дис. на здобуття наук. ступеня д-ра юрид. наук зі спеціальності 12.00.08 «Кримінальне право та кримінологія, кримінально-виконавче право». Київський національний університет внутрішніх справ. Київ, 2007.
} 
In addition, the comparison of the criminal legislation of Ukraine and the US is one of the key links ofEuro-Atlantic integration processes, since it directly promotes the convergence, harmonization and enrichment of two different legal families - the Romano-Germanic and Anglo-American ${ }^{27}$.

Subsection 9 "Bankruptcy" in Section 18 of the US Code on Crimes and Criminal Procedure provides an explanation of the term "debtor" (the subject of this group of crimes). This subsection also establishes liability for the following actions: $\S 156$. Consciously ignoring bankruptcy law; $\S 157$. Bankruptcy fraud.

Other subsections criminalize the following: $\S 212$. Offer a loan or remuneration to a financial institution expert; $\S 213$. Acceptance of a loan or remuneration by a financial institution expert; $\S 655$. Theft by a Banking Expert; $\S 656$. Theft, depredation or misuse committed by a bank employee; $\S 657$. Credit and insurance institutions; $\S 1005$. Bank records, reports and transactions; $\S 1011$. Federal Land Bank Mortgage Transactions; $\S 2313$. Bank robbery and related crimes and other abuses.

Subsection 42 of Section 18 in Section 18 of the US Code on Crimes and Criminal Procedure is titled "Credit Transactions" and contains 5 applicable criminal laws that establish liability for unlawful acts with credit: § 891-894, § 896, for example: $\S 892$. Requirement to extend credit; $\S 893$. Financing of extortion, extension of credit; $\S 894$. Collection of credit through extortion.

In 1970, the Bank Secrecy Act ${ }^{28}$ (BSA) was adopted in the United States to counteract illegal money laundering and the use of hidden accounts in foreign banks. There were introduced some activities aimed at combating various schemes of illegal proceeds' legalization. Significant in this system was the development of a regulatory framework for regulating the activities of financial institutions. The BSA, in its provisions, contains requirements for the control of every cash transfer of more than $\$ 10.000$. In addition, this document sets standards, violation of which entails civil or criminal responsibility. State control over transactions conducted by US financial institutions is also ensured through an extensive network of organizations with appropriate oversight functions.

\footnotetext{
27 Савченко А.В. Порівняльний аналіз кримінального законодавства України та федерального кримінального законодавства Сполучених Штатів Америки: дис. на здобуття наук. ступеня д-ра юрид. наук зі спеціальності 12.00 .08 «Кримінальне право та кримінологія, кримінально-виконавче право». Київський національний університет внутрішніх справ. Київ, 2007.

28 The Bank Secrecy Act of 1970 (BSA), the Currency and Foreign Transactions Reporting Act. URL: https://en.wikipedia.org/wiki/Bank_Secrecy_Act (Last accessed: 23.11.2019).
} 
Another step to combat the illegal proceeds' legalization was the adoption of The Money Laundering Control Act ${ }^{29}$ in 1986, according to which the legalization and laundering of illegal proceeds were criminalized. In particular, according to the mentioned legal act, three types of crimes in the field of money laundering were identified. Namely: the deliberate provision of assistance to credit institutions by employees in conducting transactions that may be carried out with a view to illegal proceeds' legalizing; inciting third parties to launder large amounts (over one hundred thousand US dollars) of illegal activity; deliberate fragmentation of money transfers in order to circumvent the relevant BSA requirements. The commitment of these crimes is punishable by a fine, the amount of which can reach 500 thousand US dollars or payout of double amount of laundered money, with confiscation of property, and restriction of freedom for up to 20 years.

Also, in 1986, the Complex Law on Money Laundering came into force, which imposes an obligation on credit institutions to work on accounting of all primary documentation on non-cash transactions in the sphere of trade and services, postal and telegraphic money transfers, as well as bank, cash and traveler's checks worth more than $\$ 3.000^{30}$.

According to Federal law, bank fraud in the United States is declared illegal under the provisions of the criminal law on banking fraud. In particular, Section 18 of US Code $\S 1344$ states the following ${ }^{31}$. Anyone who knowingly commits or attempts to commit the following acts: 1) misleading a financial institution or 2) the receipt of any funds, loans, assets, securities or other property owned, supervised or controlled by a financial institution in the form of misrepresentation or fraudulent use, statements or promises is punishable by a fine not exceeds $\$ 1.000 .000$, or imprisonment for not more than 30 years, or the use of both penalties.

Banking fraud legislation was passed by Congress in response to the Supreme Court decision in United States v. Williams ${ }^{32}$, which found that check-kiting schemes do not constitute false statements to financial institutions. Subsequently, § 1344 of the United States Code was backed up by the "Financial Institutions Reform, Support and Enforcement Act" in $1989^{33}$.

\footnotetext{
29 The Money Laundering Control Act of 1986 (Public Law 99-570). URL: https://en.wikipedia. org /wiki/Money_Laundering_Control_Act (Last accessed: 23.11.2019).

30 Москаленко Н.В. Досвід США щодо побудови системи запобігання та протидії легалізації доходів, отриманих злочинним шляхом. Финансы, учет, банки. 2014. № 1 (20). С. 211.

31 U.S. Code. Title 18. Part I. Chapter 63. § 1344 - Bank Fraud. Cornell Law School Legal Information Institute.

32 Williams V. United States, 458 U.S. 279 (1982). URL: https://supreme.justia.com/cases/ federal/us/-458/279/ (Last accessed: 23.11.2019).

33 FIRREA, Pub. L. No. 101-73, 103 Stat. 500. URL: https://www.govinfo.gov/ content/pkg/ STATUTE-103 /pdf/STATUTE-103-Pg183.pdf (Last accessed: 0212.2019).
} 
The Financial Institutions Reform, Recovery and Enforcement Act of 1989 is a Federal Law of the United States that provided state aid to the bankrupt loan and savings associations. Significant changes were made to the oversight system of these institutions, and enhanced equity standards. Under the provisions of the law corporation trust have been established (Resolution TrustCorporation) forclosing and merging associations bankrupt, Corporation financing (Resolution Funding Corporation) for accumulating of financing for closure and merger of bankrupt, Fund insurance savings associations instead Corporation insurance and loan savings associations. In addition, the powers of the Federal Home Loan Board were transferred to the new Office of Thrift Supervision, and 12 Federal Housing Banks were transferred to the newly created Federal Housing Finance Board.

Law on bank fraud $(\S 1344)^{34}$ in the United States criminalized checkkiting, non-disclosure of loan applications, unauthorized use of ATMs, credit card fraud and similar offenses. $§ 1344$ of the US Code does not cover certain forms of money laundering, bribery, and the passing of invalid checks. Check-kiting is illegal manipulation of monetary funds for the period of time when they are transferred from one bank to another, i.e. manipulator uses the amount of time it takes to transfer money from one check to another.

At the same time, crime rates in the banking sector in recent years in the United States provide a somewhat dubious idea of the effectiveness of all the activities undertaken. In the first half of 2017, 791 banking offenses were recorded in the United States compared to 1.091 offenses in the entire 2016, indicating a negative trend ${ }^{35}$. In 2018, there was no trend towards a decrease in banking crime. However, we also believe that overall these indicators are acceptable for a country with such a large territory.

\section{CONCLUSIONS}

The analysis of the leading experience of criminal protection of the sphere of banking activity of individual states allowed to formulate proposals and to determine the effective directions of improvement of national criminal legislation on the basis of fundamental criminal law prescriptions of EU countries, as well as other states. Comparative legal research of criminal protection in the sphere of banking activity of foreign countries will help to clarify its effective provisions, which have a positive effect on minimizing criminal offenses in the investigated problems. On the other hand, such analysis allowed

\footnotetext{
34 Crime Control Act, Pub L No. 98473, 98 Stat 2147 (1984), codified at 18 USC $\S 1344$ (1983).

35 Fraud the facts 2017 . The definitive overview of payment industry fraud. Financial fraud action UK. URL: https://www.financialfraudaction.org. uk/fraudfacts17/assets/fraud the_facts.pdf (Last accessed: 02.12.2019).
} 
take into account the negative aspects of foreign experience, in particular the ineffectiveness of certain legal decisions regarding the security of banking.

At the level of criminal law, the process of "improvement" is reduced to improve the system of criminal means to ensure the security of certain social relations to the criminalization or decriminalization of some acts. We have analyzed criminal legislation in certain European countries, including Bulgaria, Poland, Finland and Switzerland, and the selective provisions of Belgium's criminal law.

Based on studies of the European experience we should pay attention to norms on false bankruptcy and fraud on foreclosed property; favoring the creditor and accepting the debt by the creditor to the detriment of the interests of other creditors; subordination in enforcement proceedings; disposal of seized assets; collective liability for crimes etc. Experience of USA will be very useful for national law improvement because of existence of an effective link between jurisprudence and doctrine, functioning of individual norms and institutes that have been successfully implemented in many countries, existence of criminal laws in the field of US banking, formulation of terms of criminal law, characterized by logic and certainty, proper quality of criminal law, existence of an effective criminal justice system and system for crimes' prevention.

We decided that the experience of foreign countries in the field of legislative regulation of liability for crimes in the sphere of banking activity is useful for Ukraine, since the domestic criminal legislation, compared to the legislation of foreign countries, has reserves for improving criminal justice.

\section{SUMMARY}

Article deals with comparative and legal study on criminal protection in the banking activity sphere. The entry into force of Association Agreement between Ukraine and the European Union implies the need for adaptation measures in Ukrainian banking sector's legislation. We consider the European experience to be a priority for the domestic criminal legislation's formation regarding the elimination of gaps in the banking sector's security. Criminal legislation in certain European countries, including Bulgaria, Poland, Finland and Switzerland, selective provisions of Belgium's criminal law and also USA experience in this sphere were analyzed. Important conclusions were made as a result of adaptation measures' generalization of in all spheres of Ukrainian legislation. Based on studies of the European experience we should pay attention to norms 
on false bankruptcy and fraud on foreclosed property; favoring the creditor and accepting the debt by the creditor to the detriment of the interests of other creditors; subordination in enforcement proceedings; disposal of seized assets; collective liability for crimes etc. Experience of the USA will be very useful for national law's improvement because of existence of an effective link between jurisprudence and doctrine, functioning of individual norms and institutes that have been successfully implemented in many countries, existence of criminal laws in the field of US banking, formulation of terms of criminal law, characterized by logic and certainty, proper quality of criminal law, existence of an effective criminal justice system and system for crimes' prevention.

\section{REFERENCES}

1. Безвізовий діалог між Україною та ЄС. План дій злібералізаціївізового режиму. Схвалено на саміті Україна - Європейський Союз 22 листопада 2010 р., м. Брюссель, Королівство Бельгія. URL: http://zakon2.rada.gov.ua/ laws/show/984_001/paran2\#n2 (Last accessed: 14.02.2020).

2. Буряк О.П. Банківська система США. Сталий розвиток економіки. Міжнародний науково-виробничий журнал. 2015. № 1.

3. Волженкин Б.В. Экономические преступления. Санкт-Петербург : Юридический центр Пресс, 1999. 312 с.

4. Волченко Н.В., Клєцова Н.В. Правові засади банківської безпеки в контексті європейської інтеграції України. Юридичний науковий електронний журнал. 2017. № 6. C. 127-130. URL: http://www.lsej.org.ua/ 6_2017/36.pdf (Last accessed: 11.01.2020).

5. Гребенюк О.Н. Фінансова безпека банків: система розпізнання загроз та усунення ризиків. Вісник Харківського національного університету імені В.Н. Каразіна. Серія «Економічна». 2016. Вип. 91. С. 62.

6. Грищук В.К., Пасєка О.Ф. Кримінальна відповідальність юридичних осіб: порівняльно-правове дослідження : монографія. Львів : Львівський державний університет внутрішніх справ, 2013. 248 с.

7. Каменський Д.В. Кримінальна відповідальність за податкові злочини за федеральним законодавством США : автореф. дис. на здобуття наук. ступеня канд. юрид. наук: спец. 12.00.08 «Кримінальне право та кримінологія; кримінально-виконавче право». Київ, 2010. 20 с.

8. Клочко А.М. Досвід зарубіжних країн у сфері боротьби зі злочинністю. Свропейські перспективи. 2012. № 3, ч. 2. С. 132-135.

8. Кримінальний кодекс Республіки Польща від 01.01.1997 p. URL: http://law.edu.ru/norm/norm.asp?normID=1246817\&subID=100110056,100 110058\#text (Last accessed: 20.10.2019). 
9. Кримінальний кодекс Швейцарії від 21.12.1937 р. (станом на 12.07.2012 p.). URL: http://law.edu.ru/norm/norm.asp?norm ID=1241950\&s ubID $=100098712,100098714,100098872,100099142,100099154$ \#text (Last accessed: 22.10.2019).

10. Матвійчук В.К., Гіда О.С., Прилуцький Р.Б. та ін. Протидія злочинності та адаптація кримінального законодавства і права України до законодавства і права Європейського Союзу : монографія. / за заг. ред. д-ра юрид. наук, проф. В.К. Матвійчука. Київ : ВНЗ «Національна академія управління», 2014. 552 с.

11. Нерсесян А.С. Кримінально-правова охорона прав інтелектуальної власності. Хмельницький : Видавництво Хмельницького університету управління та права, 2010. 192 с.

12. Панов В.П. Международное уголовное право : учебное пособие. Москва, 1997. 241 с.

13. Про Загальнодержавну програму адаптації законодавства України до законодавства Європейського Союзу: Закон України. Вiдомості Верховної Ради України (ВВР). 2004. № 29. Ст. 367. URL: https://zakon. rada.gov.ua/laws/show/1629-15 (Last accessed: 14.02.2020).

14. Про Концепцію Загальнодержавної програми адаптації законодавства України до законодавства Свропейського Союзу : Закон України від 21 листопада 2002 р. 228-IV. Відомості Верховної Ради України. 2003. № 3. Ст. 12.

15. Савченко А.В. Порівняльний аналіз кримінального законодавства України та федерального кримінального законодавства Сполучених Штатів Америки : дис. на здобуття наук. ступеня д-ра юрид. наук зі спеціальності 12.00 .08 «Кримінальне право та кримінологія, кримінально-виконавче право». Київський національний університет внутрішніх справ. Київ, 2007.

16. Трюхан В. Інституційне забезпечення адаптації законодавства України до надбання спільноти в рамках виконання майбутньої Угоди про асоціацію Україна - ЄС. Вісник Національної академії державного управління. 2011. № 4. C. 232. URL: http://visnyk.academy.gov.ua/wp-content/ uploads/2013/11/2011-4-31.pdf (Last accessed: 20.01.2020).

17. Угода про асоціацію між Україною, 3 однієї сторони, та Європейським Союзом, Європейським співтовариством з атомної енергії і їхніми державами-членами, 3 іншої сторони. Редакція від 30.11.2015, підстава - v2980321-15. URL: https://zakon.rada.gov.ua/laws/ show/984_011 (Last accessed: 10.09.2019).

18. Crime Control Act, Pub L No. 98473, 98 Stat 2147 (1984), codified at 18 USC $\S 1344$ (1983).

19. Criminal Code of the Republic of Bulgaria (1968, amended 2017) (English version). URL: file:///C:/Users/Пользователь/Downloads/Bulgaria Criminal_Code_1968_am2017_ENG.pdf. (Last accessed: 23.11.2019). 
20. Fighting fraud in banking with big data and analytics. White paper. IBM Corporation Software Group. URL: http://www-07.ibm.com/au/ pdf/Fighting _ Fraud_in_Banking_with_Analytics.pdf.

21. FIRREA, Pub. L. No. 101-73, 103 Stat. 500. URL: https://www. govinfo.gov/content/pkg/STATUTE-103/pdf/STATUTE-103-Pg183.pdf (Last accessed: 02.12.2019).

22. Fraud the facts 2017. The definitive overview of payment industry fraud. Financial fraud action UK. URL: https://www.financialfraudaction.org. uk/fraudfacts17/assets/fraud_the_facts.pdf(Last accessed: 02.12.2019).

23. German Criminal Code (as amended up to Act of October 30, 2017). URL: https://ec.europa.eu/anti-trafficking/sites/antitrafficking/files/criminal_ code_germany_en_1.pdf(Last accessed: 23.11.2019).

24. Jayaprakash Nair. Analytics Applied - Fraud prevention and detection in the Banking sector. URL: http://blog.aspiresys.com/digital/big-data-analytics/ analytics-applied-fraud-prevention-and-detection-in-the-banking-sector/ (Last accessed: 15.12.2019).

25. The Bank Secrecy Act of 1970 (BSA), the Currency and Foreign Transactions Reporting Act. URL: https://en.wikipedia.org/ wiki/Bank Secrecy_Act (Last accessed: 23.11.2019).

26. The Money Laundering Control Act of 1986 (Public Law 99-570). URL: https://en.wikipedia.org/wiki/Money_Laundering_Control_Act (Last accessed: 23.11.2019).

27. U.S. Code. Title 18. Part I. Chapter 63. § 1344 - Bank Fraud. Cornell Law School Legal Information Institute.

28. Williams V. United States, 458 U.S. 279 (1982). URL: https://supreme. justia.com/cases/federal/us/-458/279/ (Last accessed: 23.11.2019).

Information about authors:

Klochko A. M.,

Ph.D., Associate Professor, Head of International Relations Chair Law Faculty

Sumy National Agrarian University 160, Gerasim Kondratiev str., Sumy, Ukraine

Volchenko N. V., Ph.D., Associate Professor, Associate Professor of International Relations Chair Law Faculty

Sumy National Agrarian University 160, Gerasim Kondratiev str., Sumy, Ukraine

DOI https://doi.org/10.30525/978-9934-588-43-3/2.7 